\title{
JUKMAS
}

Jurnal Untuk Masyarakat Sehat (JUKMAS)

e-ISSN : 2715-7687

Vol. 4, No. 1 April 2020

P-ISSN : 2715-8748

\section{Hubungan Antara Herediter Dan Perilaku Dengan Hipertensi Pada Lansia Di Puskesmas Mekarmukti Kabupaten Bekasi Tahun 2018}

\author{
Fitria Sari, Nuryani \\ Fakultas IImu Kesehatan, Universitas Respati Indonesia \\ Email : fitria_sari@urindo.ac.id
}

\begin{abstract}
ABSTRAK
Lanjut usia (lansia) adalah kelompok penduduk yang berumur 60 tahun atau lebih. Berdasarkan riset kesehatan dasar tahun 2013 penyakit terbanyak pada lanjut usia adalah hipertensi $(57,6 \%)$, dengan bertambah usia, maka tekanan darah sistolik cenderung naik sehingga menyebabkan hipertensi. Maka perlunya diteliti faktor-faktor yang berhubungan dengan hipertensi pada lansia. Penelitian ini bertujuan untuk mengetahui hubungan antara herediter dan perilaku dengan hipertensi pada lansia. penelitian ini menggunakan pendekatan kuantitatif rancangan "Cross Sectional". Populasi penelitian ini adalah seluruh lansia yang ada di Puskesmas Mekarmukti Kabupaten Bekasi tahun 2018. Sample diambil dengan cara sampling incident sebanyak 85 orang sesuai kriteria inklusi dan ekslusi. Hasil menunjukan dari 85 lansia yang diteliti jumlah lansia yang memiliki hipertensi yaitu $56,5 \%$, hasil analisa bivariat menunjukan dari 3 variabel yang diteliti ada 2 variabel yang memiliki hubungan yang bermakna dengan hipertensi yaitu Herediter $(p=0,001)$ dan kebiasaan merokok $(p=0,006)$. Sedangkan yang tidak memiliki hubungan bermakna ada 1 variabel yaitu latihan fisik $(p=0,986)$. Terdapat hubungan yang signifikan antara herediter, kebiasaan merokok terhadap hipertensi pada lansia. Saran dari penelitian ini adalah petugas kesehatan mampu memberikan penyuluhan mengenai faktor resiko terjadinya hipertensi pada lansia, pola hidup yang sehat, seperti menjauhi kebiasaan merokok dan melakukan latihan fisik yang teratur, Selain itu lansia harus melakukan cek kesehatan secara rutin setiap bulannya.
\end{abstract}

Daftar bacaan : 16 Literatur (2008-2015)

Kata kunci : Herediter, perilaku, lansia dan hipertensi

\section{ABSTRACT}

Elderly (elderly) is a group of residents aged 60 years or more. Based on basic health research in 2013, most diseases in the elderly were hypertension (57.6\%), with age, systolic blood pressure tends to rise, causing hypertension. So the need to study the factors associated with hypertension in the elderly. This study aims to determine the relationship between heredity and behavior with hypertension in the elderly. This study uses a quantitative approach to the "Cross Sectional" design. The population of this research is all the elderly in Mekarmukti Health Center in Bekasi District in 2018. Samples were taken by sampling as many as 85 people according to inclusion and exclusion criteria. The results showed that of the 85 elderly studied, the number of elderly people who had hypertension was $56.5 \%$, the results of the bivariate analysis showed that of the 3 variables studied there were 2 variables that had a significant relationship with hypertension namely Hereditary $(p=0.001)$ and smoking habits $(p=0.006)$. While there is no significant relationship between the variables, namely physical exercise $(p=0.986)$. There is a 
significant relationship between hereditary, smoking habits against hypertension in the elderly. Suggestions from this study are health workers able to provide counseling about risk factors for hypertension in the elderly, healthy lifestyles, such as avoiding smoking habits and doing regular physical exercise. In addition, the elderly must do regular health checks every month.

Reading list : : 16 Literatures (2008-2015)

Keywords : Hereditary, behavior, elderly and hypertension

\section{A. LATAR BELAKANG}

Menurut World Health Organization (WHO) lanjut usia (lansia) adalah kelompok penduduk yang berumur 60 tahun atau lebih. Secara global pada tahun 2009 menunjukan lansia berjumlah 7,9\% dari total populasi, tahun 2011 menjadi 7,9\% pada tahun 2013 proporsi dari populasi penduduk berusia lebih dari 60 tahun adalah $11,7 \%$ dari total populasi dunia dan di perkirakan jumlah tersebut akan terus meningkat seiring dengan peningkatan usia hidup (WHO, 2015). ${ }^{1}$

Jumlah proporsi lansia di Indonesia juga bertambah setiap tahunnya. Di Indonesia jumlah lansia mencapai 20,24 juta jiwa, setara dengan 8,03 persen dari seluruh penduduk Indonesia tahun 2014. Jumlah lansia perempuan lebih besar daripada laki-laki, yaitu 10,77 juta lansia perempuan dibandingkan 9,47 juta lansia laki-laki. Adapun lansia yang tinggal di pedesaan sebanyak 10,87 juta jiwa, lebih banyak daripada yang tinggal di perkotaan sebanyak 9,37 juta jiwa. (Statistik Penduduk Lanjut Usia, 2014). ${ }^{2}$

Masalah kesehatan pada lansia berawal dari kemunduran sel-sel tubuh, sehingga fungsi dan daya tahan tubuh menurun serta faktor resiko terhadap penyakit pun meningkat, masalah kesehatan yang sering di alami lansia adalah malnutrisi, gangguan keseimbangan, kebingungan mendadak, dan lainlain, selain itu beberapa penyakit yang sering terjadi pada lanjut usia antara lain hipertensi, gangguan pendengaran dan penglihatan, demensia, osteoporosis dan sebagainnya (Kemenkes, 2015). ${ }^{3}$ Sedangkan profil kesehatan Indonesia 2016 mencatat bahwa penyakit terbanyak pada lanjut usia berdasarkan riset kesehatan dasar tahun 2013 adalah hipertensi $(57,6 \%)$, artritis $(51,9 \%)$, struk $(46,1 \%)$, masalah gigi dan mulut 
$(19,1 \%)$, penyakit paru obstruktip menahun $(8,6 \%)$ dan diabetes mellitus $(4,8 \%)$.

Profil Kesehatan Indonesia 2016 mencatat bahwa data lansia di Jawa Barat pada tahun 2016 mencapai 2.481.860 jiwa. Sedangkan jumlah lansia di Kabupaten Bekasi mencapai 24.411 jiwa (Badan Pusat Statistik, 2014). ${ }^{2}$

Kesehatan pada lansia pada umumnya juga akan terjadi penurunan ukuran dari organ-organ tubuh tetapi tidak pada jantung. Jantung pada lansia umumnya akan membesar. Hal ini nantinya akan berhubungan dengan kelainan pada sistem kardiovaskuler yang akan menyebabkan gangguan pada tekanan darah seperti hipertensi. Berdasarkan sebabnya hipertensi dibagi menjadi hipertensi primer dan sekunder. penyebab penyakit tersebut tidak diketahui dan timbul akibat kondisi tertentu misalnya ginjal atau tumor. Hipertensi sering menimbulkan gejala mengantuk, kebingungan, gangguan penglihatan, mual dan muntah (Agoes, 2011). ${ }^{4}$

Penelitian (Febby Nanang, Hendra 2013 ) 5 di Puskesmas Telaga Murni Cikarang Barat dengan responden yang menderita hipertensi sebesar $(30,7 \%)$ sedangkan responden yang tekanan darahnya normal sebesar $(69,3 \%)$.

Menurut penelitian (Agustina,dkk 2014) ${ }^{6}$ faktor - faktor yang mempengaruhi lanjut usia yaitu keturunan dengan hipertensi pada lansia di atas umur 65 tahun.

Berdasarkan studi pendahuluan yang dilakukan peneliti pada tanggal 02 Februari tahun 2018 di Puskesmas Mekarmukti bahwa ada sekitar \pm 753 orang lansia yang berkunjung ke Poli lansia, data tersebut diambil dari bulan November 2017 sampai Februari 2018 di poli lansia. Lansia yang datang ke Puskesmas dengan keluhan terbanyak adalah hipertensi, diabetusmelitus dan Cardio Heart Failure. Berdasarkan data Profil Puskesmas Mekarmukti periode 3 tahun terakhir yaitu pada tahun 2015 jumlah lansia yang berkunjung ke Poli lansia dengan Hipertensi sebanyak 160 orang $(29,6 \%)$, pada tahun 2016 sebanyak 208 orang $(51,7 \%)$ dan pada tahun 2017 sebanyak 210 orang (31,2\%). Sedangkan pada bulan November 2017 sampai Februari 2018 hipertensi pada lansia sebanyak 73 orang (31,2\%). (Puskesmas Mekarmukti). ${ }^{5}$

Dengan bertambah usia, maka tekanan darah sistolik cenderung naik 
sehingga menyebabkan Hipertensi.

Tekanan darah dapat meningkat

\section{B. METODE PENELITIAN}

\section{Pendekatan Penelitian}

Penelitian ini menggunakan pendekatan kuantitatif dengan menggunakan rancangan Cross Sectional, yaitu pengambilan data yang dikumpulkan pada suatu waktu sama untuk lebih mempersingkat waktu (Notoatmodjo, 2012). ${ }^{7} \quad$ Dalam penelitian ini pengambilan variabel bebas dan variabel terikat dilakukan secara bersamaan (pengumpulan data), yaitu Hubungan antara Herediter dan perilaku dengan hipertensi pada lansia di Puskesmas Mekarmukti Kabupaten Bekasi tahun 2018. Hasil dari pengukuran disajikan dalam bentuk tabel distribusi frekuensi dan tabel silang.

\section{Waktu dan Tempat Penelitian}

Penelitian dilakukan di
Puskesmas
Kabupaten Bekasi Pelaksanaan
penelitian ini dilakukan pada
bulan Maret - Agustus 2018

3. Instrumen Penelitian (terutama sistolik) setelah mengonsumsi rokok dan alcohol.

Instrument penelitian ini adalah alat-alat yang mengukur fenomena alam maupun sosial yang diamati, secara spesifik semua fenomena disebut variable penelitian (Sugiyono, 2017). Instrument yang digunakan dalam penelitian ini berupa Kuesioner. Pengambilan data dilakukan setelah memberikan penjelasan terlebih dahulu tentang tujuan dan cara penelitian serta meminta kesediaan dari responden untuk menjadi sampel penelitian, kemudian responden diminta untuk mengisi kuesioner dengan lengkap.

\section{Populasi dan Sampel Penelitian}

\section{a. Populasi}

Populasi penelitian adalah keseluruhan objek penelitian atau objek yang diteliti (Notoatmodjo, 2010). ${ }^{7}$ Populasi dalam penelitian ini adalah lansia yang hipertensi di Puskesmas Mekarmukti yang berjumlah 753 orang lansia. Berdasarkan data pada bulan November 2017 sampai bulan Februari 2018.

\section{b. Sampel}


Sampel dalam penelitian ini adalah seluruh lansia yang berada di wilayah kerja Puskesmas Mekarmukti yang berjumlah 85 orang. Dalam penelitian ini teknik pengambilan sampel menggunakan teknik sampling incidental yaitu teknik penentuan sampel berdasarkan kebetulan yaitu siapa saja yang secara kebetulan/ incidental bertemu dengan peneliti dapat digunakan sebagai sampel, bila dipandang orang yang kebetulan ditemui itu cocok sebagai sumber data( Sugiyono, 2011 ). ${ }^{8}$

\section{Teknik Pengumpulan Data}

Data yang diperoleh dalam penelitian ini adalah data primer

\section{Analisis Data}

a. Analisis Univariat

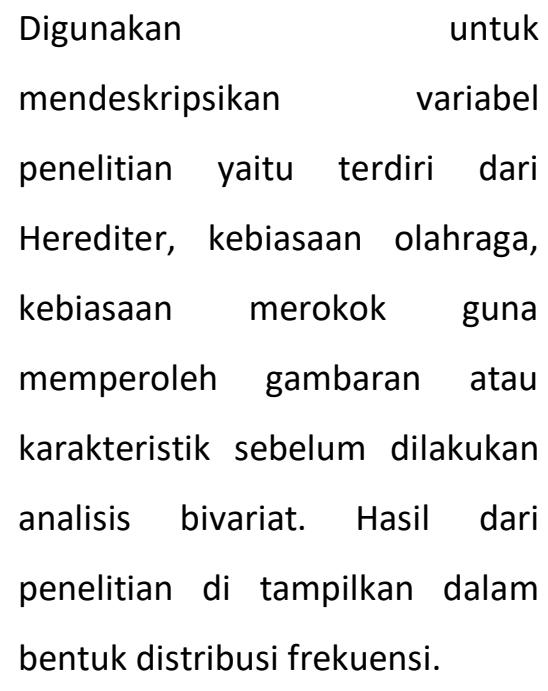

\section{b. Analisis Bivariat}

Analisis bivariat adalah
analisis yang dilakukan untuk
mengetahui hubungan antara
variabel bebas dan variabel
terikat dengan menggunakan uji
statistic Chi-Square yaitu variabel
bebas (Hipertensi) dengan
variabel terikat (Herediter,
kebiasaan olahraga dan
kebiasaan merokok).

C. HASIL PENELITIAN

1. Hasil Analisis Univariat

Tabel 5.1 Distribusi frekuensi hipertensi pada lansia di Puskesmas Mekarmukti tahun 2018

\begin{tabular}{ccc}
\hline Hipertensi & $\begin{array}{c}\text { Frekue } \\
\text { nsi (n) }\end{array}$ & $\begin{array}{c}\text { Persent } \\
\text { ase (\%) }\end{array}$ \\
\hline $\begin{array}{l}\text { Hipertensi } \\
\text { Tidak } \\
\text { Hipertensi }\end{array}$ & 48 & 56,5 \\
\hline TOTAL & 37 & 43,5 \\
\hline
\end{tabular}

Tabel 5.2 Distribusi frekuensi herediter pada lansia di Puskesmas Mekarmukti tahun 2018

\begin{tabular}{|c|c|c|}
\hline Herediter & $\begin{array}{c}\text { Frekuensi } \\
\text { (n) }\end{array}$ & $\begin{array}{c}\text { Persentase } \\
(\%)\end{array}$ \\
\hline $\begin{array}{l}\text { Ada } \\
\text { Keturunan }\end{array}$ & 48 & 56,5 \\
\hline $\begin{array}{l}\text { Tidak Ada } \\
\text { Keturunan }\end{array}$ & 37 & 43,5 \\
\hline TOTAL & 85 & 100,0 \\
\hline \multicolumn{3}{|c|}{$\begin{array}{l}\text { Tabel 5.3 Distribusi frekuensi } \\
\text { kebiasaan merokok pada lansia di } \\
\text { Puskesmas Mekarmukti tahun } 2018\end{array}$} \\
\hline $\begin{array}{c}\text { Kebiasaan } \\
\text { Merokok }\end{array}$ & $\begin{array}{c}\text { Frekuensi } \\
\text { (n) }\end{array}$ & $\begin{array}{c}\text { Persentase } \\
\text { (\%) }\end{array}$ \\
\hline Merokok & 26 & 30,6 \\
\hline $\begin{array}{l}\text { Tidak } \\
\text { Merokok }\end{array}$ & 59 & 69,4 \\
\hline
\end{tabular}




\begin{tabular}{|c|c|c|}
\hline TOTAL & 85 & 100,0 \\
\hline \multicolumn{3}{|c|}{$\begin{array}{l}\text { Tabel } 5.4 \text { Distribusi frekuensi latihan } \\
\text { fisik pada lansia di Puskesmas } \\
\text { Mekarmukti tahun } 2018 \text {. }\end{array}$} \\
\hline Latihan Fisik & $\begin{array}{l}\text { Frekuensi } \\
\text { (n) }\end{array}$ & $\begin{array}{c}\text { Persentase } \\
(\%)\end{array}$ \\
\hline
\end{tabular}

\begin{tabular}{|c|c|c|}
\hline $\begin{array}{c}\text { Tidak } \\
\text { melakukan }\end{array}$ & 38 & 44,7 \\
\hline $\begin{array}{l}\text { Latihan fisik } \\
\text { Melakukan } \\
\text { Latihan fisik }\end{array}$ & 47 & 55,3 \\
\hline TOTAL & 85 & 100,0 \\
\hline
\end{tabular}

2. Hasil Analisis Bivariat

Tabel 5.6

Hubungan antara herediter dengan hipertensi pada lansia di Puskesmas Mekarmukti Kabupaten Bekasi tahun 2018

\begin{tabular}{|c|c|c|c|c|c|c|c|c|}
\hline \multirow{3}{*}{ Herediter } & \multicolumn{4}{|c|}{ Hipertensi } & \multirow{2}{*}{\multicolumn{2}{|c|}{ Total }} & \multirow{3}{*}{$P_{\text {Value }}$} & \multirow{3}{*}{$\begin{array}{c}\text { OR }(95 \% \\
C I)\end{array}$} \\
\hline & \multicolumn{2}{|c|}{$\mathrm{Ya}$} & \multicolumn{2}{|c|}{ Tidak } & & & & \\
\hline & $\mathbf{n}$ & $\%$ & $\mathbf{n}$ & $\%$ & $\mathbf{n}$ & $\%$ & & \\
\hline Ada keturunan & 35 & 72,9 & 13 & 27,1 & 48 & 100,0 & & 4.970 \\
\hline $\begin{array}{l}\text { Tidak ada } \\
\text { keturunan }\end{array}$ & 13 & 35,1 & 24 & 64,9 & 37 & 100,0 & 0,001 & (1,965- \\
\hline Jumlah & 48 & 56,5 & 37 & 43,5 & 85 & 100,0 & & 12,כ/U \\
\hline
\end{tabular}

Tabel 5.7

Hubungan antara kebiasaan merokok dengan hipertensi pada lansia di Puskesmas Mekarmukti Kabupaten Bekasi Tahun 2018

\begin{tabular}{|c|c|c|c|c|c|c|c|c|}
\hline \multirow{3}{*}{$\begin{array}{c}\text { Kebiasaan } \\
\text { merokok }\end{array}$} & \multicolumn{4}{|c|}{ Hipertensi } & \multirow{2}{*}{\multicolumn{2}{|c|}{ Total }} & \multirow{3}{*}{$\mathbf{P}_{\text {Value }}$} & \multirow{3}{*}{ OR $(95 \% \mathrm{Cl})$} \\
\hline & \multicolumn{2}{|c|}{$\mathrm{Ya}$} & \multicolumn{2}{|c|}{ Tidak } & & & & \\
\hline & $\mathbf{N}$ & $\%$ & $n$ & $\%$ & $n$ & $\%$ & & \\
\hline Merokok & 21 & 80,8 & 5 & 19,2 & 26 & 100,0 & & 4,978 \\
\hline $\begin{array}{c}\text { Tidak } \\
\text { merokok }\end{array}$ & 27 & 45,8 & 32 & 54,2 & 59 & 100,0 & 0,006 & $\begin{array}{l}4,910 \\
(1,654- \\
14,978)\end{array}$ \\
\hline Jumlah & 48 & 56,5 & 37 & 43,5 & 85 & 100,0 & & \\
\hline
\end{tabular}

Tabel 5.8

Hubungan antara latihan fisik dengan hipertensi pada lansia di Puskesmas Mekarmukti Kabupaten Bekasi tahun 2018

\begin{tabular}{|c|c|c|c|c|c|c|c|c|}
\hline \multirow{3}{*}{ Latihan fisik } & \multicolumn{4}{|c|}{ Hipertensi } & \multirow{2}{*}{\multicolumn{2}{|c|}{ Total }} & \multirow{3}{*}{$P_{\text {Value }}$} & \multirow{3}{*}{$\begin{array}{c}\text { OR }(95 \% \\
\mathrm{CI})\end{array}$} \\
\hline & \multicolumn{2}{|c|}{$\mathrm{Ya}$} & \multicolumn{2}{|c|}{ Tidak } & & & & \\
\hline & $n$ & $\%$ & $\mathbf{N}$ & $\%$ & $\mathbf{n}$ & $\%$ & & \\
\hline $\begin{array}{l}\text { Tidak latihan } \\
\text { fisik }\end{array}$ & 22 & 57,9 & 16 & 42,1 & 38 & 100,0 & & 1,111 \\
\hline $\begin{array}{l}\text { Melakukan } \\
\text { latihan fisik }\end{array}$ & 26 & 55,3 & 21 & 44,7 & 47 & 100,0 & 0,986 & $\begin{array}{l}(0,468- \\
2,633)\end{array}$ \\
\hline Jumlah & 48 & 56,5 & 37 & 43,5 & 85 & 100,0 & & \\
\hline
\end{tabular}




\section{PEMBAHASAN}

\section{Hipertensi}

Berdasarkan tabel 5.1 dapat diketahui bahwa dari 85 lansia berdasarkan penyakit Hipertensi yaitu 48 orang $(56,5 \%)$ memiliki penyakit Hipertensi dan 37 orang $(43,5 \%)$ tidak memiliki Hipertensi.

\section{Herediter}

Berdasarkan tabel 5.2
menggambarkan bahwa dari 85
lansia berdasarkan herediter yaitu
sebanyak 48 orang (56,5 \%) memiliki
faktor keturunan hipertensi, dan 37
orang (43,5\%) tidak memiliki faktor
keturunan hipertensi.
Berdasarkan tabel 5.6 didapatkan
bahwa dari 85 responden lansia
yang hipertensi berjumlah 35 orang
$(72,9 \%)$ yaitu dengan memiliki keturunan hipertensi, dan responden lansia yang tidak hipertensi berjumlah 24 orang $(64,9 \%)$ yang tidak mempunyai keturunan hipertensi. Hasil uji statistik diperoleh nilai $\mathrm{P}_{\text {value }}=0,001$ maka dapat disimpulkan ada hubungan antara Herediter dengan hipertensi dengan diperoleh nilai $O R=4,970$.

Penelitian ini sejalan dengan yang dilakukan oleh (Sutanto, 2010) yang mengatakan sebagian besar kasus hipertensi dipengaruhi oleh faktor keturunan. Jika kedua orang tua memiliki riwayat penyakit hipertensi anaknya akan beresiko terkena hipertensi, terutama pada hipertensi primer (essensial) hal ini terjadi karena adanya gen yang berhubungan dengan kejadian hipertensi yang menurun pada dirinya.

Berdasarkan hasil penelitian diatas maka peneliti berasumsi bahwa hipertensi dapat dipengaruhi oleh faktor keturunan /pola pewarisan berdasarkan genetik mencapai 30\%. Pola pewarisan /keturunan disebabkan jika orangtua mengalami hipertensi maka akan menurunkan kepada anaknya dan diantara responden yang memiliki keturunan hipertensi sebagian banyak diturunkan oleh ibu dan bapaknya.

\section{Kebiasaan merokok}

Berdasarkan tabel 5.3 di atas menggambarkan bahwa dari 85 lansia berdasarkan kebiasaan merokok yaitu ada 26 orang (30,6 \%) yang memiliki kebiasaan merokok dan 59 orang $(69,4 \%)$ tidak memiliki kebiasaan merokok.

Berdasarkan tabel 5.7 bahwa dari 85 responden lansia. yang memiliki 
kebiasaan merokok yang buruk yang memilik penyakit hipertensi berjumlah 21 orang $(80,8 \%)$ dan lansia yang tidak memiliki kebiasaan merokok dan tidak memiliki hipertensi yaitu 32 orang (54,2\%). Hasil uji statistic didapatkan nilai $P_{\text {value }}=0,006$ maka dapat disimpulkan ada hubungan antara kebiasaan merokok dengan hipertensi pada lansia, diperoleh nilai $\mathrm{OR}=4,978$.

Penelitian ini sejalan dengan penelitian (Arif dkk, 2013). ${ }^{9}$ menyatakan bahwa kebiasaan merokok dengan kejadian Hipertensi pada lansia di Pusling Desa Khumpit UPT Puskesmas Gribig menunjukan bahwa ada hubungan antara keduanya bersifat searah dimana lansia yang mempunyai kebiasaan merokok akan beresiko untuk mengalami hipertensi.

Hal ini sejalan dengan pendapat (Maryam 2008). ${ }^{10}$ Penghentian konsumsi rokok dan alcohol terbukti dapat menurunkan tekanan darah. Meskipun mekanisme nya tidak diketahui, tekanan darah dapat meningkat (terutama sistolik) setelah mengonsumsi rokok dan alcohol. Menghentikan penggunaan rokok pada pengidap hipertensi penting untuk mengurangi resiko beberapa penyakit yang dapat dipicu oleh hipertensi, seperti stroke dan serangan jantung.

Berdasarkan hasil penelitian diatas maka peneliti berasumsi bahwa bahwa lansia yang merokok lebih beresiko hipertensi karena zat nikotin dan karbondioksida yang terkandung dalam rokok akan merusak pembuluh darah sehingga dapat menyebabkan tekanan darah meningkat. Sebagian besar lansia mengatakan merokok hanya kadangkadang dan sebagian lagi mengatakan pernah merokok dan sudah berhenti.

\section{Latihan fisik}

Berdasarkan tabel 5.3 di atas menggambarkan bahwa dari 85 lansia berdasarkan kebiasaan merokok yaitu ada 26 orang $(30,6 \%)$ yang memiliki kebiasaan merokok dan 59 orang $(69,4 \%)$ tidak memiliki kebiasaan merokok.

Berdasarkan Tabel 5.8 bahwa lansia yang hipertensi berjumlah 22 orang $(57,9 \%)$ yang tidak melakukan latihan fisik, dan ada 21 orang $(44,7 \%)$ lansia yang tidak hipertensi dan melakukan latihan fisik Hasil uji statistik diperoleh nilai $P_{\text {value }}=0,986$ maka dapat disimpulkan tidak ada 
hubungan yang bermakna antara latihan fisik dengan hipertensi.

Menurut teori (Agoes, 2011). ${ }^{4}$ Olahraga penurunan berat badan dan olahraga aerobic yang teratur dapat mencegah terjadinya hipertensi ringan dan sedang. Olahraga yang teratur akan memperbaiki frekuensi denyut jantung dan tekanan darah.

Penelitian ini tidak sejalan dengan penelitian yang dilakukan oleh (Hernelahti M, Kujala UM, Kaprio J, et.al dalam Tri Novitaningtyas 2014) ${ }^{11}$ menyatakan bahwa tidak teratur melakukan olahraga akan meningkatkan resiko terkena hipertensi sebesar 2,33 kali dibandingkan yang teratur berolahraga.

Menurut asumsi peneliti bahwa olahraga yang dilakukan lansia masih belum sepenuhnya baik. Hal ini disebabkan Pada saat mereka melakukan latihan fisik, jenis latihan, waktu dan intensitas lamanya latihan fisik yang dilakukan kurang tepat sehingga tidak sesuai dengan standar kesehatan lansia. Sebagian besar lansia mengatakan latihan fisik dilakukan hanya 1-2x dalam seminggu dan lamanya latihan fisik selama 5-10 menit dan hanya berjalan-jalan disekitar rumah.

\section{E. SIMPULAN}

Dari hasil penelitian tentang hubungan antara herediter dan perilaku dengan hipertensi pada lansia di Puskesmas Mekarmukti Kabupaten Bekasi tahun 2018 yang dilakukan pada bulan Maret-Agustus 2018 kepada 58 lansia adalah sebagai berikut:

1. Lansia yang memiliki hipertensi sebanyak 48 orang $(56,5 \%)$ dan 37 orang $(43,5 \%)$ lansia yang tidak memiliki hipertensi.

2. Lansia yang memiliki herediter/ keturunan dengan hipertensi sebanyak 35 orang $(72,9 \%)$

3. Kebiasaan merokok pada lansia sebagian besar pada kategori lansia hipertensi sebanyak 21 orang $(80,8 \%)$

4. Latihan fisik pada lansia lebih banyak tidak di lakukan oleh lansia yang hipertensi yaitu 22 orang $(57,9 \%)$

\section{DAFTAR PUSTAKA}

1. WHO, 2011. Hypertension Fact Sheet. Department of Sustainable Development and Healthy Environments 2011 http://www.searo.who.int/linkfiles/ non_communicable_diseases_hyper tension fs.pdf diperoleh pada tanggal 10 maret 2018 
2. Statistik Penduduk Lanjut Usia, 2014. Diterbitkan oleh Badan Pusat Statistik, Jakarta-Indonesia 2015 Https://www.bapenas.go.id >files $>d$ $\underline{\text { ata }}$ di akses tanggal 10 maret 2018

3. Kementrian Kesehatan Ri. Profil kesehatan $2015 . \quad$ Jakarta: Kementrian Kesehatan RI, 2016. www.depkes.go.id >download $>$ gene ral

4. Agoes A, Agoes A, Agoes A. 2011. Penyakit Usia Tua, Jakarta; Penerbit Buku Kedokteran.

5. Febby Haendra Dwi Anggara1, Nanang Prayitno Jurnal IImiah Kesehatan, 5(1); Jan 2013 FaktorFaktor Yang Berhubungan Dengan Tekanan Darah Di Puskesmas Telaga Murni, Cikarang Barat Tahun 2012. https://www.nhlbi.nih.gov/files/doc s/guidelines/express.pdf

6. Agustina, Sari, Savita, Faktor-Faktor yang Berhubungan dengan Hipertensi Pada Lansia di Atas Umur 65 Tahun file:///D:/lansia/lansia/701-123-1-10-20170209.pdf
7. Notoatmodjo, 2011.Kesehatan Masyarakat Ilmu dan Seni. Jakarta; PT Rineka Cipta.

8. Sugiyono, 2011. Metode Penelitian Kuantitatif Kualitatif Dan R\&D, Bandung; ALFABETA, CV

9. Arif, Rustono, Hartinah, 2013, Faktor-Faktor Yang Berhubungan Dengan Kejadian Hipertensi Pada Lansia Di Pusling Desa Klumpit Upt Puskesmas Gribig Kabupaten Kudus, [internet] D Arif, R Rusnoto, D Hartinah-...ilmu keperawatan dan...,2013-ejr.stikesmuhkudus.ac.id

10. Maryam dkk, 2008. Mengenal Usia Lanjut dan Perawatannya, Jakarta; Salemba Medika

11. Hernelahti M, Kujala UM, Kaprio J, et.al dalam Aris 2007 dalam Tri Novitaningtiyas, 2014 (Hubungan karakteristik umur, jenis kelamin, tingkat pendidikan dana aktivitas fisik dengan tekanan darah pada lansia di kelurahan makamhaji kecamatan kartasura kabupaten Sukoharjo). Diakses tanggal 14 mei 2018 